\title{
BARISTŲ FIZINIŲ YPATYBIŲ IR LAIKYSENOS POKYČIAI, TAIKANT KINEZITERAPIJĄ
}

\author{
Vaiva Strukčinskaitė ${ }^{1,2}$, Greta Blauzdžiūnaitė ${ }^{2}$, Birutẻ Strukčinskienė ${ }^{3}$, \\ Emilija Griškonyte் ${ }^{4}$, Sigitas Griškonis ${ }^{3,5}$ \\ ${ }^{1}$ Vilniaus universiteto Medicinos fakulteto Sveikatos mokslu institutas, \\ ${ }^{2}$ Vilniaus kolegijos Sveikatos priežiūros fakulteto Reabilitacijos katedra, \\ ${ }^{3}$ Klaipeddos universiteto Sveikatos mokslu fakultetas, ${ }^{4}$ Lietuvos sveikatos mokslu universiteto \\ Medicinos akademijos Medicinos fakultetas, ${ }^{5}$ Klaipédos universitetine ligonine
}

Raktažodžiai: fizinės ypatybės, laikysena, kineziterapija, ilgalaikis stovėjimas, darbo aplinka, baristai.

\begin{abstract}
Santrauka
Straipsnyje aptariamos baristų darbo stovimoje padètyje pasekmès, analizuojamas kineziterapijos poveikis šio darbo specifikos paveiktoms baristų fizinèms ypatybẻms ir laikysenai. Tyrimo tikslas - ịvertinti kineziterapijos poveikị baristų laikysenai ir fizinėms ypatybėms. Tirti 19-25 metu baristai. Tiriamojoje grupeje buvo 16, o kontrolinejje -15 baristų (iš viso 31 ). Naudota mokslinès literatūros analizè, testavimas. Atlikti tiriamujų antropometriniai matavimai (matuotas ūgis, svoris ir KMI). Laikysena vertinta taikant W.W.Hoeger laikysenos vertinimo skalę. Fizinès ypatybès analizuotos taikant Rufjè testą (aerobinès ištvermès vertinimas), atliekant liemens raumenų statinès ištvermès vertinimą pagal McGill metodiką, stuburo paslankumo vertinimą, 90-90 testą (tiesios blauzdos kèlimo testas) ir Y pusiausvyros testą. Tyrimo rezultatai atskleidè, kad išanalizavus visų tiriamujų rodiklius prieš tyrimą, pastebètas normų neatitikimas. Puikios laikysenos normų neatitiko 35,5 proc. tiriamujų, didelio aerobinio pajègumo - 58,1 proc., pilvo-nugaros bei kairiojo-dešiniojo šonų raumenų statinès ištvermès normų atitinkamai 41,9 ir 12,9 proc., PGA normos neatitiko 45,2 proc. tiriamujų. Taikant kineziterapiją tiriamojoje grupeje, pagerèjo visos fizinès ypatybės ir laikysena. Kontrolinèje grupejje laikysena nepakito, o fizinès ypatybės kito nežymiai. Analizuojant tiriamosios ir kontrolinès grupių kineziterapijos efektyvumą pastebèta, kad kineziterapija, atliekama prižiūrint specialistui, yra efektyvesnè, nes specialistas turi žinių ir ịūdžių pastebèti bei koreguoti
\end{abstract}

pratimus ar laikyseną. Savarankiškai atliekama kineziterapijos procedūra gali tapti nesaugi, nes jei asmuo nebus kompetentingas pratimų metu pastebèti savo klaidų, jos netaisomos gali tapti žalingomis. Atliekant kineziterapijos programą savarankiškai, negalima motyvacija ir neužtikrinama šios programos vykdymo kontrolè.

\section{İvadas}

XXI a. apie darbo ergonomiką galima rasti daug informacijos, tačiau darbuotojai ne visada apmokomi jos principus taikyti darbo metu. Norint pakeisti stovimoje padètyje dirbančių žmonių sveikatinimą, kuris Lietuvoje dar nèra labai paplitęs, svarbu koreguoti laikyseną ir gerinti fizines ypatybes. Jei žmogaus laikysena taisyklinga, raumenynas stiprus, laikomasi ergonomikos, tai stovimas darbas nebus žalingas dirbant ir ilgesnị laiką [1].

2014 metais Lietuvoje vidutinio fizinio aktyvumo stovimą darbą dirbo 49 proc. vyrų ir 51 proc. moterų [2]. Tai sudaro beveik pusę Lietuvos gyventojų, kuriems galimi stovimo darbo padariniai. Stovimas darbas yra pèdų, blauzdų, nugaros skausmo, kojų tinimo, venų varikozės, pečių juostos įtampos, netaisyklingos laikysenos rizikos veiksnys. Dirbant stovimą darbą vargsta kojų raumenys, iskausta nugara, gali deformuotis stuburo tarpslanksteliniai diskai, atsirasti išvaržų. Aktyvus stovimas darbas gali būti priskirtas fiziniam aktyvumui, kuris reikalingas ir naudingas palaikyti sveikatą ir darnią žmogaus organų veiklą. Reguliarus fizinis aktyvumas gerina savijautą, fizinè veikla teikia pasitenkinimą, kūnas tampa stangresnis ir gyvybingesnis. Tai puiki susirgimų profilaktikos ir gydymo priemonè [3]. Vis dèlto ilgalaikis stovejjimas negali būti vienintelè fizinio aktyvumo raiškos forma žmogaus gyvenime, nes ilgainiui 
darosi žalingas. Pasaulio mokslininkai nustate, kad stovimas darbas, kartu su vaikščiojimo greičiu, rūkymu, kojų ir viso kūno skausmu bei kt. genetiniu lygmeniu koreliuoja su venų varikoze $[4,5]$. Stovimam darbui atlikti reikia rinktis patogią avalynę. Netinkama avalynė deformuoja stovèseną, kuri ilgainiui formuoja netaisyklingą laikyseną. J. Anderson ir kt. (2017) atliko tyrimą su virtuves ir veterinarijos ligoninès darbuotojais, įrodžiusi, jog netinkama avalynė sukelia ne vien pėdų skausmus, bet ir didina skeleto-raumenų pažeidimų ir traumų darbe riziką. Tyrejjai rekomenduoja rinktis stovimo darbo specifikai pritaikytą avalynę, nes ši mažina pėdų skausmus ir pažeidimų bei traumų riziką darbe [6]. Ilgalaikis stovimas darbas gali sukelti nugaros skausmus. Dažniausiai šis skausmas prasideda tada, kai atskiros netreniruoto organizmo raumenu grupès apkraunamos ilgą laiką $[7,8]$. R. Dainty ir kt. (2014) atlikto tyrimo duomenimis, 68 proc. dirbančiu baristų apklausos metu atsaké, jog dirbdami jaučia skausmą pečių juostoje [9]. Statinès apkrovos metu blogeja kraujotaka, jaučiamas skausmas ir nuovargis. Dèl ilgalaikès funkcinès imobilizacijos ir statinio krūvio atsiranda klubo, kelių ir stuburo sąnarių mikrotraumatizacija, galinti sukelti reumatoidinius susirgimus [10]. Lyginant stovimą padètị su sėdima, buvo nustatyta, jog palaikyti stovimą padètį reikia apie 10 proc. daugiau energijos [11]. Aktyvus ilgalaikis darbas stovimoje padettyje savaime nèra žalingas, tačiau ilgainiui jis formuoja netaisyklingą stovèseną, o ši - netaisyklingą laikyseną. Nors toks darbo pobūdis ir gali būti priskiriamas fiziniam aktyvumui, tačiau

1 lentelè. Bendroji tiriamųų charakteristika

\begin{tabular}{|c|c|c|c|c|c|c|c|c|}
\hline \multirow{2}{*}{$\begin{array}{c}\text { Bendri } \\
\text { duomenys }\end{array}$} & \multicolumn{4}{|c|}{ Tiriamoji grupè } & \multicolumn{4}{|c|}{ Kontrolinė grupė } \\
\hline & Vidurkis & Moda & Min & Max & Vidurkis & Moda & Min & Max \\
\hline Amžius (m.) & 21,5 & 21 & 19 & 24 & 20,9 & 20 & 19 & 25 \\
\hline Ūgis (cm) & 172,7 & 172 & 163 & 190 & 169,1 & 164 & 162 & 181 \\
\hline Svoris (kg) & 65 & 72 & 54 & 74 & 62,3 & 62 & 56 & 70 \\
\hline $\mathrm{KMI}\left(\mathrm{kg} / \mathrm{m}^{2}\right)$ & 21,8 & 19,9 & 18,9 & 25,3 & 21,9 & 23,1 & 18,8 & 25,7 \\
\hline $\begin{array}{l}\text { Darbo trukmé } \\
\text { (mèn.) }\end{array}$ & 17,1 & 24 & 5 & 36 & 14,7 & 12 & 5 & 43 \\
\hline
\end{tabular}

2 lentelè. Tiriamųjų laikysenos, W.W. Hoeger testu įvertintos mažiau nei 5 balais, kūno dalių vertinimo rezultatai

\begin{tabular}{|l|c|c|c|c|c|c|}
\hline \multirow{2}{*}{ Kūno dalis } & \multicolumn{2}{|c|}{$\begin{array}{c}\text { Bendroji } \\
\text { grupé }\end{array}$} & \multicolumn{2}{c|}{$\begin{array}{c}\text { Kontrolinė } \\
\text { grupé }\end{array}$} & \multicolumn{2}{c|}{$\begin{array}{c}\text { Tiriamoji } \\
\text { grupé }\end{array}$} \\
\cline { 2 - 7 } & $\begin{array}{c}\text { prieš } \\
\text { tyrimą }\end{array}$ & $\begin{array}{c}\text { po ty- } \\
\text { rimo }\end{array}$ & $\begin{array}{c}\text { prieš } \\
\text { tyrimą }\end{array}$ & $\begin{array}{c}\text { po ty- } \\
\text { rimo }\end{array}$ & $\begin{array}{c}\text { prieš } \\
\text { tyrimą }\end{array}$ & $\begin{array}{c}\text { po } \\
\text { tyrimo }\end{array}$ \\
\hline 1. Pečiai & 24 & 11 & 10 & 10 & 14 & 1 \\
\hline 2. Stuburas & 4 & 4 & 3 & 3 & 1 & 1 \\
\hline $\begin{array}{l}\text { 3. Kaklas ir viršutine } \\
\text { stuburo dalis }\end{array}$ & 10 & 6 & 4 & 4 & 6 & 2 \\
\hline 4. Pilvas & 5 & 4 & 3 & 3 & 2 & 1 \\
\hline 5. Apatine stuburo dalis & 19 & 17 & 13 & 13 & 6 & 4 \\
\hline 6. Kojos & 4 & 2 & 2 & 2 & 2 & 0 \\
\hline
\end{tabular}

jis nèra pakankamas ir tikslingas lavinti fizines ypatybes.

Vieni iš ilgalaikio stovimo darbo atstovu yra kavos ruošejai - baristai. Tai prie baro stovimą darbą dirbantieji, kavos aparatu naudotis gebantieji kavos menininkai, ruošiantys, puošiantys ir tiekiantys kavos (kartais ir arbatos) gerimus klientams. Baristai dirba kavinèje, bare ar restorane. Itališkai barista - kavos ruošimo meistras.

Tyrimo tikslas - ịvertinti kineziterapijos poveikị baristų laikysenai ir fizinèms ypatybèms.

\section{Tyrimo medžiaga ir metodai}

Buvo tirti vidutinio dydžio verslo įmonių baristai. Tyrimo imtis 31 baristas. Tiriamojoje grupeje buvo 16, o kontrolinèje -15 baristų. Itraukimo ị tyrimą kriterijai: baristai, dirbantys bent 5 mènesius, amžius nuo 19 iki 25 metų, sutinkantys dalyvauti tyrime. Neįtraukimo kriterijai: ūmūs nugaros skausmai, širdies ir kraujagyslių ligos (hipertenzija ir kt.). Tiriamieji prieš tyrimą buvo supažindinti su tyrimo paskirtimi, eiga, metodais, testavimo procedūromis ir gydymo specifika.

Tyrimo metu naudota mokslinès literatūros analizè, testavimas. Atlikti tiriamujų antropometriniai matavimai. Matuotas ūgis, svoris ir kūno masės indeksas (KMI). Laikysena vertinta taikant W.W.Hoeger laikysenos vertinimo skalę. Fizinès ypatybès analizuotos taikant Rufjè testą (aerobinès ištvermès vertinimas), liemens raumenų statinès ištvermès vertinimą pagal McGill metodiką, stuburo paslankumo vertinimą, 90-90 testą (tiesios blauzdos kèlimo testas) ir Y pusiausvyros testą. Tyrimo metu buvo siekiama ịvertinti kineziterapijos poveikị baristų laikysenai bei fizinèms ypatybėms ir palyginti pasiektus dviejų grupių rezultatus, kurių viena programą grupeje atliko prižiūrima kineziterapijos specialisto, o kita - individualiai. Tiriamieji buvo testuojami prieš ir po tyrimo. Siekiant palyginti šių grupių, kineziterapijos efektyvumą, tyrimo metu gauti rezultatai buvo apdoroti ir palyginti tarpusavyje.

Statistinei duomenų analizei buvo naudojama MS Excel programa ir statistinių programų paketas SPSS 21.0. Taikyta aprašomoji statistika. Tiriamujų požymiams ịvertinti buvo apskaičiuojami ir pateikiami vertingų rodiklių aritmetiniai vidurkiai, moda bei minimalios ir maksimalios reikšmès. Rezultatai statistiškai reikšmingi, kai $\mathrm{p}<0,05$.

\section{Tyrimo rezultatai ir jų aptarimas}

Tiriamujų amžius svyravo nuo 19 iki 25 metų, amžiaus vidurkis 21,28 metų. Ūgis svyravo nuo 162 iki $190 \mathrm{~cm}$, o svoris - nuo 54 iki $74 \mathrm{~kg}$. Tiriamujų ūgio vidurkis buvo 171, $24 \mathrm{~cm}$, svorio vidurkis - 
$63,92 \mathrm{~kg}$. Baristėmis dirbančių merginų KMI vidurkis buvo $21,84 \mathrm{~kg} / \mathrm{m}^{2}$, kuris pagal Pasaulio sveikatos organizacijos (PSO) paskelbtus indeksus rodo normalų svorį. Tiriamujų darbo trukmè svyravo nuo 5 iki 43 mènesių, darbo trukmès vidurkis apie 16 mènesių ( 1 lentelè).

Tyrimo metu buvo analizuojama baristėmis dirbančiu merginų laikysena, naudojant W.W. Hoeger laikysenos vertinimo testą. Tiriamojoje grupejje prieš tyrimą laikysena buvo įvertinta 45,07, o kontrolineje - 45,3 balais. Po tyrimo kontrolinès grupès rezultatas nepakito, o tiriamojoje buvo stebimas statistiškai reikšmingas 3,07 balų vidutinès vertès pokytis; laikysena buvo įvertinta 48,13 balų $(\mathrm{p}<0,05)$.

Analizuojant W. W. Hoeger testu atliktą kūno dalių vertinimą, geros laikysenos nukrypimai pastebeti 6 atvejais iš 10: pečiai, stuburas, kaklas ir viršutinè stuburo dalis, pilvas, apatinè stuburo dalis, kojos. Netaisyklinga laikysena pastebèta: pečių dalies 77 proc. tiriamujų, stuburo -13 proc., kaklo ir viršutinės stuburo dalies -32 proc., pilvo - 16 proc., apatinès stuburo dalies -61 proc., kojų -13 proc. tiriamujuc ( 2 lentelè). Antrojo testavimo metu kontrolinės grupès rezultatai buvo nepakitę, o tiriamojoje 62,5 proc. baristų surinko didžiausią galimą šio testo balų (50) skaičių.

Tiriamujų aerobinè ištvermè vertinta Rufjè testu. Ben-

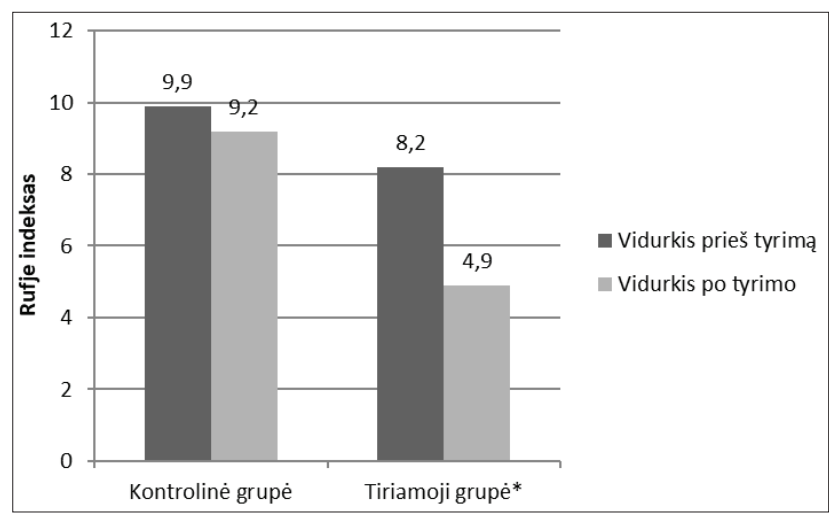

1 pav. Rufjè indeksas prieš ir po tyrimo ${ }^{*} \mathrm{p}<0,05$

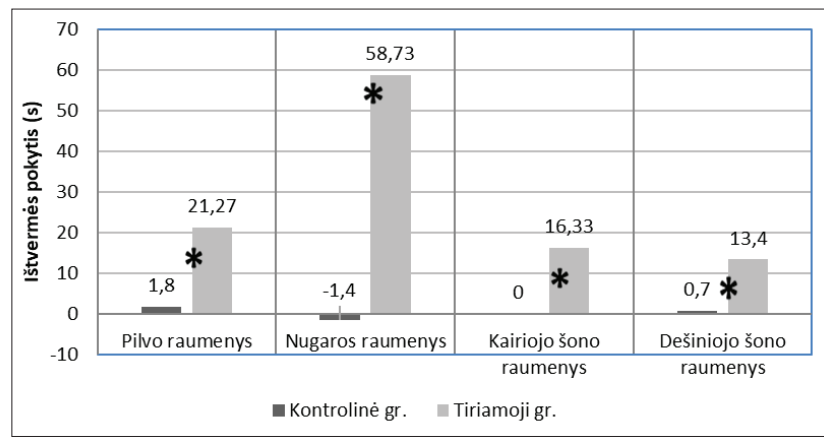

2 pav. Liemens raumenų statinès ištvermès pokytis, $\mathrm{s} * \mathrm{p}<0,05$ drosios grupès indekso vidurkis prieš tyrimą buvo beveik 9 , po tyrimo nesieké 7 , tačiau abu šie indeksai patenka ị vieną aerobinès ištvermès vertinimo intervalą, kuris interpretuojamas kaip vidutinis pajègumas. Analizuodami abiejų grupių indekso vidurkị prieš tyrimą, nustateme, jog kontrolinès grupés jis yra 9,9 , o tiriamosios 8,2 , tačiau abi grupès patenka i vidutinio pajègumo intervalą (1 pav.). Didesniam kontrolinès grupès Rufjè indeksui įtaką galèjo daryti didesnis tiriamujuų, turinčių didesni KMI, skaičius, negu tiriamosios grupès. Stebint abiejų grupių Rufjè indekso vidurkio pokyčius po tyrimo, matoma, jog kontrolinès grupès vidurkis siekia 9,2, o tiriamosios $-4,9$. Tiriamoji grupè indeksą sumažino 3,4 vienetais ir iš vidutinio pajègumo intervalo pateko ị didelio aerobinio pajègumo intervalą $(\mathrm{p}=0,000)$. Kontroliné grupe indeksą sumažino 0,7 vienetais ir išliko vidutinio pajègumo grupeje, indekso pokytis statistiškai nereikšmingas $(\mathrm{p}=0,304)$.

Tyrimo metu buvo vertinama baristų liemens raumenu statinè ištvermè. Grupių viduje visi liemens raumenų statinès ištvermès rezultatai po tyrimo ryškiai pakito tik tiriamosios grupès, kurios dalyvių rezultatai statistiškai reikšmingai pagerëjo: pilvo raumenų statinès ištvermès rezultatas padidèjo $21,27 \mathrm{~s}(\mathrm{p}=0,043)$, nugaros raumenų 58,73 $\mathrm{s}(\mathrm{p}=0,000)$, liemens kairiojo šono raumenų $16,33 \mathrm{~s}(\mathrm{p}=0,000)$, dešiniojo šono raumenų 13,4 $\mathrm{s}(\mathrm{p}=0,000)$. Kontrolinès grupès liemens

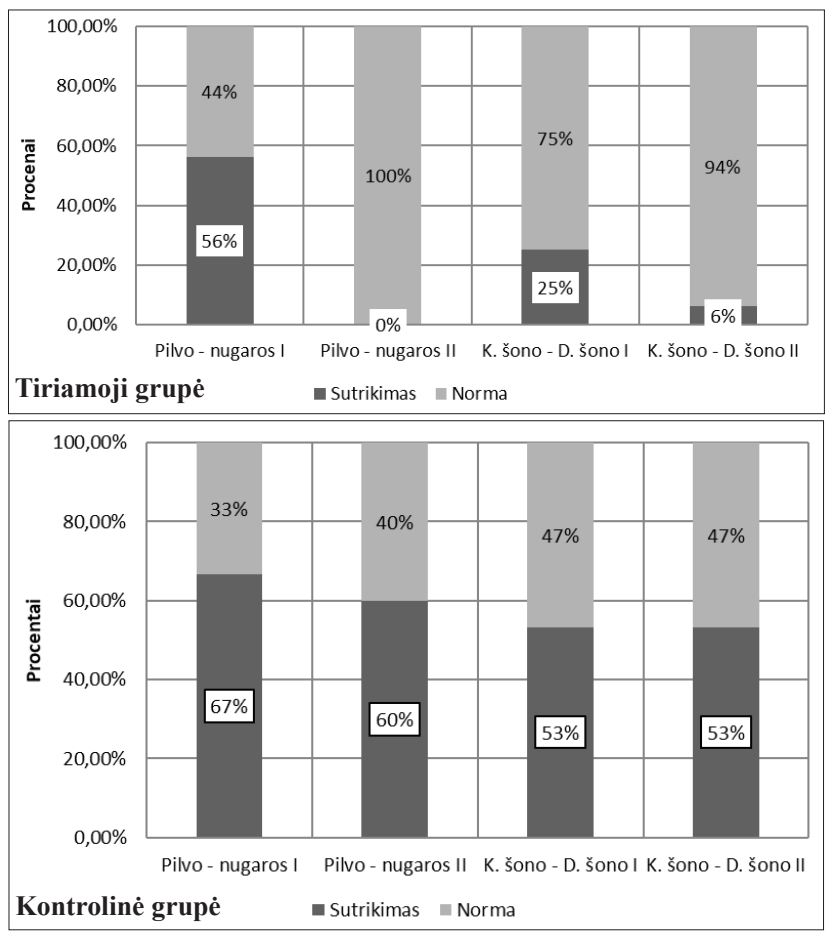

3 pav. Liemens raumenų statinės ištvermès santykių normų atitiktis tiriamojoje ir kontrolinèje grupèse 
raumenų statinès ištvermès rezultatai po tyrimo beveik nepakito arba kito statistiškai nereikšmingai, $p>0,05$. Tiriamosios grupès pilvo, nugaros, liemens kairiojo ir dešiniojo šonų raumenų statinès ištvermės pokyčiai buvo žymiai ryškesni, nei kontrolinės (2 pav.).

Pilvo ir nugaros raumenų statinès ištvermès testavimo rezultatai buvo analizuojami pagal $2002 \mathrm{~m}$. McGill pateiktas rezultatu išraiškos sekundèmis interpretacijas: 20-30 s norma, 15-20 s gerai, 10-15 s patenkinamai, 1-10 s silpnai atliktas testas. Kadangi daugumos tiriamujų, atitikusių normą, rezultatai buvo žymiai didesni nei $30 \mathrm{~s}$, rezultatus tikslingiau analizuoti nagrinejjant santykius tarp skirtingų raumenų grupių statinès ištvermès rezultatų. Pilvo-nugaros raumenų statinès ištvermės santykių rezultatai tiriamojoje ir kontrolinèje grupèse prieš tyrimą buvo atitinkamai 1,36 ir 1,06 , po tyrimo 1,48 ir 1,11. Šio santykio pokytis tiriamojoje grupeje buvo teigiamas $0,13, p=0,718$, kontrolinejje teigiamas, bet nežymus $0,04, p=0,891$. Kairès ir dešinės pusès liemens šoninių raumenų statinès ištvermès santykis tiriamojoje grupeje kilo nuo $0,93 \mathrm{iki}$ $1,11, \mathrm{p}=0,253$, kontrolinèje grupejje - nuo 1,05 iki $1,13, \mathrm{p}=0,800$. Tiriamosios grupés santykių atitikimas normas parodytas 3 pav. viršuje. Pilvo-nugaros raumenų statinès ištvermès santykių normą

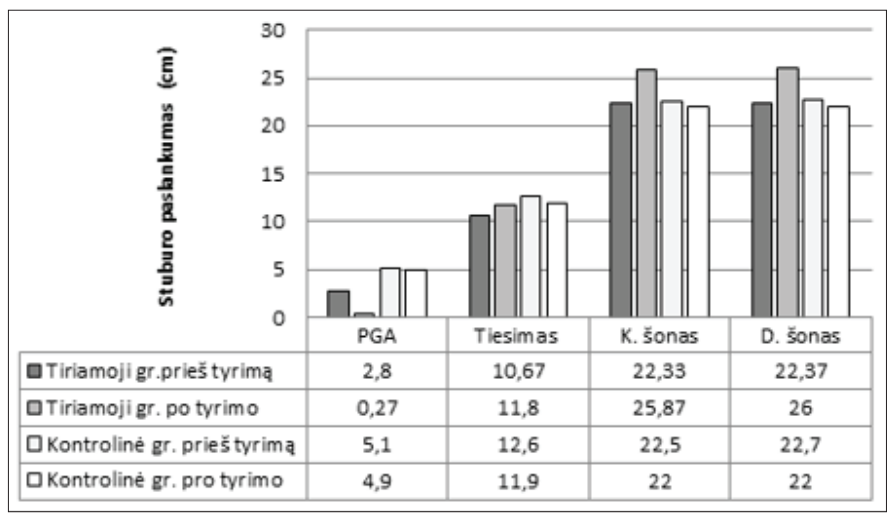

4 pav. Stuburo paslankumo vertinimas grupèse prieš ir po tyrimo

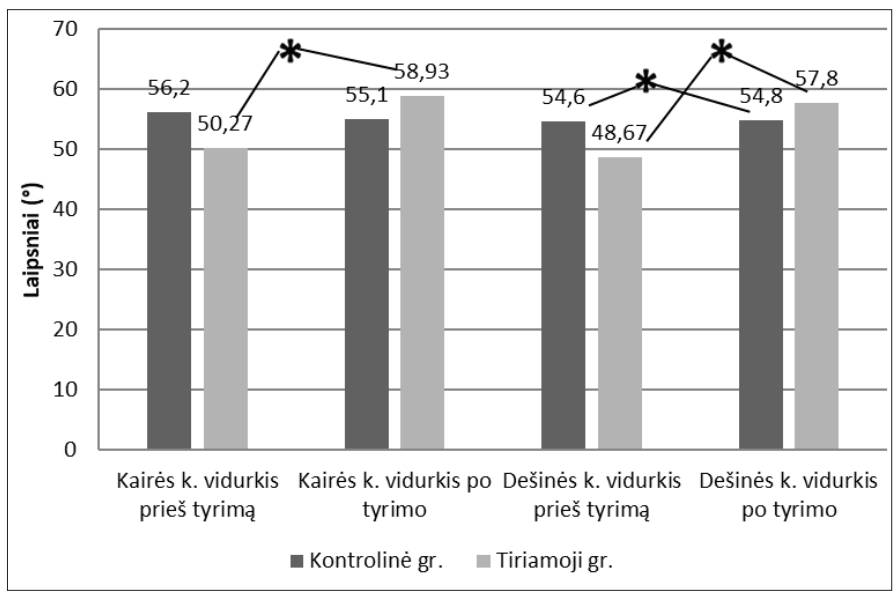

5 pav. $90-90$ testo vidurkiai tiriamojoje ir kontrolineje grupėse $\left({ }^{*} \mathrm{p}<0,05\right)$ prieš tyrimą atitiko 44 proc., o po tyrimo - 100 proc. tiriamujų. Kairiojo-dešiniojo liemens šono raumenų statinès ištvermès santykių normas prieš tyrimą atitiko 75 proc., po tyrimo - 94 procentai tiriamujų. Tiriamojoje grupeje po tyrimo normas atitikusių tiriamųju skaičius didejo. Kontrolinès grupès liemens raumenų statinès ištvermès santykių atitikimas normas parodytas 3 pav. apačioje. Pilvo-nugaros raumenų statinès ištvermès santykių normą prieš reabilitaciją atitiko apie 67 proc., o po tyrimo - 33 proc. tiriamujų. Kairiojo-dešiniojo liemens šono raumenų statinès ištvermès santykių normas prieš tyrimą atitiko apie 47 proc., po tyrimo šis skaičius nepakito. Kontrolineje grupejje po tyrimo statinès ištvermès testo normas atitikusių tiriamųų skaičius beveik nepakito.

Tyrimo metu buvo vertinami stuburo paslankumo rodikliai - liemens lenkimas, tiesimas, šoninis lenkimas ị kairę ir ị dešinę puses. Liemens lenkimas ị priekị buvo vertinamas nustatant pirštų - grindų atstumą (PGA) (4 pav.). Visi tiriamosios grupès rodikliai gerèjo, o kontrolinès dažniausiai nežymiai prastējo. Tiriamojoje grupejje PGA rodiklis gerejjo nuo $2,8 \mathrm{~cm}$ iki $0,27 \mathrm{~cm}$, skirtumas $2,53 \mathrm{~cm}$, apvalintas liemens tiesimo rezultataspagerèjo $1,1 \mathrm{~cm}$. Šninio lenkimo ị kairę rezultatas gerejo nuo $22,33 \mathrm{~cm}$ iki $25,87 \mathrm{~cm}$, šoninio lenkimo ị dešinę kito apytikriai nuo $22,37 \mathrm{~cm}$ iki 26 $\mathrm{cm}$. Kontrolinèje grupejje PGA rodiklis buvo vienintelis pagerèjęs nuo $5,1 \mathrm{~cm}$ iki $4,9 \mathrm{~cm}$, skirtumas $0,2 \mathrm{~cm}$. Po tyrimo kontrolinès grupès rodikliai prastėjo galimai dèl tiriamujų aplaidaus požiūrio ị rekomenduojamus tempimo pratimus.

PGA - vienintelis tirtas klinikinis rodiklis, kurio rezultatai skyrèsi tarp grupių prieš tyrimą ir po jo. Prieš tyrimą PGA nuliniu rezultatu įvertinti 6 (37,5 proc.) tiriamosios grupès baristai ir 5 (50 proc.) - kontrolinès. Po tyrimo PGA nuliniu rezultatu ịvertinti 12 (75 proc.) tiriamosios grupés baristų ir 6 (60 proc.) - kontrolinès. Po tyrimo PGA rodiklis sumažèjo tiriamosios grupés 10,4, o kontrolinès - 1,04 karto.

Tyrimo metu buvo tiriama užpakalinès šlaunų pusès grupès raumenų (m. biceps brachii, $m$. semitendinosus, m. semimembranosus) įtampa. Atliekant 90-90 testą, goniometru buvo matuojama kelio sąnario amplitudè tiriamiesiems aktyviai tiesiant blauzdą. Prieš tyrimą abiejų grupių kairès kojos amplitudžių vidurkis buvo didesnis už dešinès kojos amplitudžių vidurkị. Po tyrimo kairès kojos amplitudžių vidurkis išliko didesnis, tačiau teigiamai pakito tiriamojoje grupeje nuo $50,27^{0}$ iki $58,93^{0}, p=0,000$ o kontrolinejje grupejje pakito neigiamai nuo $56,20^{\circ}$ iki $55,10^{\circ}, \mathrm{p}=0,555$. Stebint dešinès 
kojos amplitudžių vidurki abiejose grupėse, po tyrimo jis statistiškai reikšmingai pakito atitinkamai nuo $48,67^{0}$ iki $57,80^{\circ}, \mathrm{p}=0,000$ ir nuo $54,60^{\circ}$ iki $54,80^{\circ}, \mathrm{p}=0,007$ ( 5 pav.).

Testas buvo analizuojamas pagal tyrimo metoduose aprašytas normas. Jei tiriamieji negali ištiesti blauzdos daugiau nei $20^{\circ}$, tai testas yra teigiamas ir daroma prielaida, jog užpakalinès šlaunų pusės grupès raumenys yra sutrumpejję. Visų kontrolinès ir tiriamosios grupès dalyvių rezultatai prieš tyrimą atitiko normą ir testas buvo neigiamas. Minimalus kairès kojos kelio amplitudès laipsnis kontrolineje grupeje kito nuo $42^{0}$ iki $40^{\circ}$, dešinès kojos amplitudè liko nepakitusi (38 laipsniai). Minimalus kairès kojos kelio amplitudès laipsnis tiriamojoje grupeje kito nuo $22^{\circ} \mathrm{iki} 35^{\circ}$, o dešinès kojos amplitudè - nuo $32^{0}$ iki 42 laipsnių. Maksimalus kairès kojos kelio amplitudès laipsnis kontrolinèje grupeje prieš ir po tyrimo liko nepakitęs $-68^{\circ}$, dešinès kojos amplitudè pakito nuo 74 iki 75 laipsnių. Maksimalus kairès kojos kelio amplitudès laipsnis tiriamojoje grupeje nuo $72^{\circ}$ pakilo iki $82^{\circ}$, o dešinès kojos amplitudè - nuo 82 iki 86 laipsnių. Po tyrimo abiejų grupių testas išliko neigiamas, rodantis užpakalinès šlaunų pusės raumenų grupès ịtampos nebuvimą.

Tyrimo metu buvo vertinamas tiriamujjų dinaminis stabilumas Y pusiausvyros testu. Grupių tiriamieji, stovedami ant vienos kojos, priešinga koja turejjo siekti trijų krypčių: anteriorinès, posteromedialinès ir posterolateralinès, po to kita koja ir atlikti tą pati. 3 lentelèje pateikiami abiejų grupių pasiekti vidutiniai atstumai. Analizuojant atstumus galima pastebeti, jog anteriorine, posteromedialine ir posterolateraline kryptimis dešine ir kaire koja prieš tyrimą kontroliné grupe galëjo pasiekti toliau, tačiau po tyrimo tiriamosios grupès dalyviai pasiekẻ teigiamą pokytị abiem kojomis, o kontrolinès grupès tiriamieji - neigiamą. Dešine koja tiriamojoje ir kontrolinėje grupèse stebimi šie pokyčiai: anteriorine kryptimi $5 \mathrm{~cm}$ ir $-0,6 \mathrm{~cm}$, posteromedialine kryptimi 7,07 $\mathrm{cm}$ ir $-0,9 \mathrm{~cm}$, posterolateraline kryptimi $4,4 \mathrm{~cm}$ ir $-0,2 \mathrm{~cm}$. Kaire koja tiriamojoje ir kontrolinejje grupèse stebimi tokie pokyčiai: anteriorine kryptimi $5,53 \mathrm{~cm}$ ir $-0,9 \mathrm{~cm}$, posteromedialine kryptimi $5,73 \mathrm{~cm}$ ir $-0,4$ $\mathrm{cm}$, posterolateraline kryptimi $4,2 \mathrm{~cm}$ ir $-1,1 \mathrm{~cm}$.

Gauti duomenys buvo analizuojami juos lyginant su norminiais. Jei tiriamujų tos pačios krypties abiejų kojų atstumų skirtumas yra didesnis už 4 $\mathrm{cm}$, daroma prielaida, jog pusiausvyra ta kryptimi yra sutrikusi ir padideja apatinès galūnès traumų rizika. Stebint tiriamosios grupès abiejų kojų atstumo skirtumo pasiskirstymą pagal normas, pastebèta, kad anteriorine kryptimi prieš tyrimą normą atitiko 13 tiriamujų, posteromedialine kryptimi - 12, posterolateraline - 10. Po tyrimo visomis kryptimis normą atitiko visa tiriamoji grupe - 16 tiriamujų. Analizuojant kontrolinès grupés abiejų kojų atstumo skirtumą atitikimą normas, pastebèta, kad anteriorine kryptimi prieš tyrimą normą atitiko 8 tiriamieji, posteromedialine -6 , posterolateraline -3 . Po tyrimo anteriorine kryptimi normą atitiko 10 tiriamujų, posteromedialine -7 , o posterolateraline -4 (3 lentelè). Tiek tiriamosios, tiek kontrolinès grupès rezultatai kito statistiškai nereikšmingai, atliekant testą visomis kryptimis, $p>0,05$.

Tyrimo problema buvo nustatyti ilgą laiką trunkančio aktyvaus stovimo darbo poveikị baristų laikysenai ir fizinèms ypatybėms. Išanalizavus rodiklius prieš tyrimą, buvo pastebèta, kad 35,5 proc. tiriamujų neatitiko puikios laikysenos, 58,1 proc. - didelio aerobinio pajègumo, 41,9 proc. - pilvonugaros bei 12,9 proc. - kairiojo-dešiniojo šonų raumenų statinès ištvermès normų, 45,2 proc. tiriamųų neatitiko PGA normos. Tiriamojoje grupeje po tyrimo pagerejo visos fizinès ypatybės ir laikysena. Kontrolinèje grupejje laikysena nepakito, fizinès ypatybės pagerẻjo nežymiai.

Vertinant laikyseną W. W. Hoeger testu, pagerèjimas matomas tik tiriamojoje grupejje. Pagerèjo ne vien surinktu balų vidurkis, bet ir minimalus bei dažniausiai pasikartojantis surinktų balų skaičius. Po tyrimo šioje grupejje nebeliko nè vieno tiriamojo, kuris patektų i geros laikysenos balu intervalą, visi surinko 46 balus arba daugiau, tad jų laikysena puiki. Kontrolinejje grupeje po tyrimo nebuvo jokių laikysenos pakitimu - ji nepagerejjo. Tiriant odontologų, kaip stovimo darbo atstovų, laikyseną, buvo nustatyta, kokios kūno dalys darbo metu atsiranda labiausiai nenatūralioje padètyje ir būna apkraunamos. Labiausiai buvo apkrauta galva, kaklas, pečiai ir juosmuo. Galvos, kaklo ir pečiu juosta (67,9 proc.) apkraunama tiesioginio darbo su pacientais metu, juosmuo (60,3 proc.) apkraunamas skaitant pacientų dokumentaciją, o 78,2 proc. - atliekant dokumentų pildymo darbus [12]. Analizuojant tyrimo su baristais rezultatus matoma, jog lai-

3 lentelè. Tiriamosios ir kontrolinės grupių Y pusiausvyros testo rezultatai

\begin{tabular}{|c|c|c|c|c|}
\hline \multirow{3}{*}{ Kryptys } & \multicolumn{4}{|c|}{ Dešinė koja } \\
\hline & \multicolumn{2}{|c|}{ Tiriamosios grupès vidurkis } & \multicolumn{2}{|c|}{ Kontrolinės grupės vidurkis } \\
\hline & Prieš tyrimą & Po tyrimo & Prieš tyrimą & Po tyrimo \\
\hline Anterior kryptis & 63,93 & 68,93 & 66,20 & 65,60 \\
\hline Posteromedialine kryptis & 74,00 & 81,07 & 79,00 & 78,10 \\
\hline Posterolateraline kryptis & 77,27 & 81,67 & 81,60 & 81,40 \\
\hline \multirow{3}{*}{ Kryptys } & \multicolumn{4}{|c|}{ Kairè koja } \\
\hline & \multicolumn{2}{|c|}{ Tiriamosios grupès vidurkis } & \multicolumn{2}{|c|}{ Kontrolinès grupès vidurkis } \\
\hline & Prieš tyrimą & Po tyrimo & Prieš tyrimą & Po tyrimo \\
\hline Anterior kryptis & 63,47 & 69,00 & 66,40 & 65,50 \\
\hline Posteromedialine kryptis & 75,73 & 81,47 & 78,90 & 78,50 \\
\hline Posterolateraline kryptis & 77,60 & 81,80 & 81,60 & 80,50 \\
\hline
\end{tabular}


kysenos pakitimai ryškiausi kaklinèje stuburo dalyje - tai pasireiške padidejjusia lordoze bei nevienodame aukštyje esančiais pečiais. Be to, stebima padidejjusi baristų juosmeninè lordozė. Šios per dideles apkrovas gaunančios zonos buvo stebimos ir tiriant odontologus.

Tyrimo metu ịvertinus aerobinę ištvermę, Rufjè testo indekso sumažejimas, rodantis aerobinès ištvermès pagerèjimą, stebimas abiejose grupèse. Lyginant tiriamają grupę su kontroline, indekso pokytis tarp ju beveik 5 kartai. Minimalus indeksas šiose grupèse taip pat sumažejo: tiriamojoje grupejje 3 kartus, kontrolinejje 2,4 karto. Ryškiausias skirtumas tarp grupių matomas maksimaliai pasiekto indekso pokyčiu, kurio skirtumas beveik 10 kartų. Po tyrimo kontrolinès grupès rodikliai atitiko vidutinio pajègumo intervalą, o tiriamosios pasiekè didelio pajègumo intervalą.

G. McRae ir kt. (2012) atliktame tyrime pirmajai grupei taikè bėgtakio treniruotę su besikeičiančiu greičiu ir ịkalne, o antrajai - keturių skirtingų pratimų pakartojimą 8 kartus po $20 \mathrm{~s}$ darant $10 \mathrm{~s}$ pertrauką. Ryškaus aerobinès ištvermès skirtumo tarp grupių nenustatyta. Tyrimas buvo atliekamas 4 savaites, vyko 4 užsièmimai po 30 minučių. Po tyrimo pirmosios grupès aerobinè ištvermé padidèjo 7 proc., o antrosios -8 proc., tačiau padaryta išvada, jog atliekant treniruotę be bègtakio, gerinama ne vien aerobinè, bet ir raumenu ištvermè [13].

Ivertinus baristų liemens raumenų statinę ištvermę, kontrolinejje grupeje pastebètas minimalus pagerejjimas arba nugaros raumenų atveju - pablogèjimas po tyrimo. Analizuojant tiriamosios grupès pokyčius, matomas ryškesnis pagerejjimas - pilvo, nugaros, dešiniojo ir kairiojo šono raumenų statinès ištvermès vidurkis pakilo atitinkamai: $21,27 \mathrm{~s} ; 58,73 \mathrm{~s} ; 13,4 \mathrm{~s}$; $16,33 \mathrm{~s}$. Kontrolineje grupeje vertinant pilvo - nugaros, kairio ir dešinio šono santykių pokytị, jis buvo labai nežymus 0,04 ir 0,07 . Po tyrimo 40 proc. tiriamujų vis dar neatitiko pilvonugaros raumenų santykio normos, o kairiojo ir dešiniojo šono raumenų santykio normos neatitiko 30 proc. tiriamujų. Analogiškai analizuojant tuos pačius kriterijus tiriamojoje grupeje, matomas ryškesnis santykių pokytis 0,13 ir 0,18 . Šioje grupeje po tyrimo pilvo-nugaros raumenų santykio normą atitiko visi tiriamieji, o kairiojo ir dešiniojo šono raumenų santykio normos neatitiko 6,25 proc. tiriamųjų. D. Teyhen ir kt. (2013) tyre 340 karių, lygindami liemens raumenų stabilizavimo pratimų programos efektyvumą su tradicinių pratimų programa, stiprinant liemens raumenų jègą. Tyrimas truko 12 savaičiu, kai 4 dienas vidutiniškai po 5 minutes buvo atliekami 5-6 pratimai po 1 minutę. Tradicinè pratimų programa buvo aukšto intensyvumo su dažnu kartojimu , o stabilizavimo programa -žemo intensyvumo su vidutiniu kartojimu. Buvo parinkti skirtingi pratimai. Tyrimo rezultatai ịrodè didesnị stabilizavimo pratimų efektyvumą, gerinant liemens raumenų ištvermę [14]. Būtent tokie pratimai ir buvo naudojami, vykdant tyrimą su baristais.

Tyrimo metu buvo vertinami stuburo paslankumo rodikliai - liemens lenkimas, tiesimas, šoninis lenkimas ị kairę ir i dešinę puses. Pagerèjimas matomas tik tiriamojoje grupeje: liemens lenkimas pagerèjo $-2,53 \mathrm{~cm}$, tiesimas $1,13 \mathrm{~cm}$, šoninis lenkimas ị kairę $3,53 \mathrm{~cm}$, ị dešinę $3,63 \mathrm{~cm}$. Kontrolinėje grupèje stebimas minimalus rezultatų suprastèjimas. Minimaliai pagerèjo tik liemens lenkimas $-0,2$ centimetro. R. Simão ir kt. (2011) tyrimas įrode, jog taikant viršutinès ir apatinès kūno dalies statinị tempimą, užlaikant jị nuo 15 iki 60 s 16 savaičių kiekvieną dieną, buvo stebimas reikšmingas stuburo paslankumo ir lankstumo pagerèjimas [15]. Remiantis tarptautiniais moksliniais tyrimais apie statinị tempimą, šie tempimai mūsų tyrime buvo įtraukti ị baristų programą.

Atliekant 90-90 (tiesios blauzdos kèlimo) testą, buvo tiriama užpakalinès šlaunies pusès grupès raumenų įtampa. Po tyrimo kairès kojos kelio amplitudžių vidurkis, kaip ir prieš tyrimą, išliko didesnis, tačiau tiriamojoje grupejje pakito teigiamai $8,67^{\circ}$, o kontrolineje - neigiamai -1,1 laipsnio. Stebint dešinès kojos kelio amplitudžių vidurkị abiejose grupèse, po tyrimo jis pakito teigiamai tiriamojoje grupeje $9,13^{\circ}$, o kontrolineje buvo -0,2laipsnio. Po tyrimo abiejose grupèse testas išliko neigiamas, t.y. pasiekta bent $20^{\circ}$ kelio amplitudè. Tai leidžia manyti apie tiriamujų užpakalinès šlaunies dalies raumenų grupès įtampos nebuvimą. Norint issitikinti, jog tempimo pratimai didina užpakalinès šlaunies pusės raumenų paslankumą, J. Muyor ir kt. (2012) atliko tyrimą su 58 tiriamaisiais. Jo metu tempimai buvo taikomi 12 savaičių. Buvo taikomos trys pozicijos, padetti išlaikant 20 s 3 kartus per savaitę darbo vietoje, pamainai pasibaigus. Ivertinus tyrimo rezultatus matyti, jog pasiektas reikšmingas pagerèjimas. Be to, šie tempimo pratimai skatino krūtininès kifozès ir priekinio dubens pasvirimo sumažèjimą [16]. Tempimo pratimų efektyvumas matomas ir tyrimo apie baristus duomenų analizès rezultatuose.

Dinaminis tiriamujų stabilumas buvo vertinamas Y pusiausvyros testu. Analizuotas pasiektas atstumas trijomis kryptimis: anteriorine, posteromedialine ir posterolateraline. Tiriamosios grupés dalyviai po tyrimo pasiekè teigiamą pokytị abiem kojomis, o kontrolinès grupès tiriamieji - neigiamą. Vertinant tiriamosios grupès rezultatus anteriorine kryptimi, prieš tyrimą normą atitiko 81,25 proc. tiriamųu, posteromedialine -75 proc. , posterolateraline $-62,5$ procentai. Po tyrimo visomis kryptimis normą atitiko visa tiriamoji grupè. Stebint kontrolinès grupès pokyčius anteriorine kryptimi prieš tyrimą, normą atitiko 80 proc. tiriamujų, posteromedialine -60 proc., posterolateraline -30 proc. Po tyrimo anteriorine kryptimi normą atitiko 100 proc. tiriamujų, posteromedialine -70 proc., o posterolateraline -40 
proc. S. Lynn ir kt. (2012) atliktas mokslinis tyrimas įrodè, kad 4 savaičių pėdų raumenų stiprinimas nedaro ryškios įtakos dinaminei pusiausvyrai, todèl norint gerinti šią fizinę ypatybę, reikètų rinktis įvairią dinaminę veiklą [17]. Tyrime su baristais šiai ypatybei gerinti, remiantis straipsniu, buvo pasirinkti dinaminiai pratimai apatinei kūno daliai su pusiausvyros ir koordinacijos elementais.

Apibendrinant tyrimą galima teigti, kad ilgą laiką trunkantis aktyvus stovimas darbas paveikia baristų laikyseną ir fizines ypatybes. Dèl nuolatinès stovimos darbo padèties laikysena tampa netaisyklinga ir ydinga, fizinès ypatybès dèl monotoniškai pasikartojančio stovimo fizinio krūvio irgi suprastėja. Tyrimo pradžioje atliktas baristų testavimas parodè, kad tiriamieji dažnai neatitiko minimalių testų normų arba jų rezultatai pateko į prastesnius intervalus. Tokius fizinių ypatybių rezultatus pradžioje paveikti galejjo žemas fizinis aktyvumas ne darbo aplinkoje. Norint atlikti informatyvesni tyrimą, prieš pradedant pradinį testavimą reikètų naudoti fizinio aktyvumo klausimyną ir ị tyrimo atrankos kriterijus įtraukti papildomos sportinès veiklos nebuvimą. Pagal tyrimo metu nustatytus beveik nepakitusius arba suprastëjusius kontrolinès grupès rezultatus, galima daryti prielaidą, jog ne visa šios grupès programa buvo sąžiningai atlikta, nes sportuojant individualiai, rezultatai neturejo suprastèti. Atliktas tyrimas būtų tikslesnis, jei būtų pašalintas pagrindinis trūkumas - negalejimas stebėti kontrolinès grupès. Problemos sprendimui galima pasinaudoti išmaniaisiais telefonais, jei kontrolinès grupés dalyviai po kiekvienos treniruotés atsiųstu po nuotrauką įsitikinti, jog jie iš tikrujų vykde programą. Būtų galima taikyti ir motyvacinę programą: susitikti kas dvi savaites, aptarti iškilusius klausimus, atnaujinti pratimu programą.

Tyrimas igalino pateikti rekomendacijų stovimoje padètyje dirbantiems žmonèms. Rekomenduojama baristams ir kitiems asmenims, dirbantiems stovimą darbą, reguliariai mankštintis (bent du kartus per savaitę), kad būtų išlaikomos optimalios fizinès ypatybès ir tinkamas fizinio aktyvumo lygis. Tai padètų išvengti žalingų stovimo darbo pasekmių ar jas sušvelninti. Būtų tikslinga stovimoje padètyje dirbančių žmonių darbo vietose pateikti lankstinukų, kuriuose aprašomi ergonomikos principai ir rekomendacijos.

\section{Išvados}

1. Aktyvus darbas stovimoje padètyje turi neigiamą poveiki, jei asmuo darbinèje aplinkoje nesilaiko ergonomikos principų, o laisvu laiku neužsiima jokia aktyvia fizine veikla.

2. Taikant kineziterapiją, tiriamosios grupès dalyvių laikysena po tyrimo reikšmingai pagerèjo $(p<0,05)$, o kontrolinès nepakito.

3. Taikant kineziterapiją, tiriamojoje grupejje po tyrimo pagerejjo visi fizinių ypatybių testavimo rezultatai, o kontrolinèje grupejje fizinès ypatybès kito nežymiai.

4. Analizuojant tiriamosios ir kontrolinès grupių kineziterapijos efektyvumą pastebėta, kad kineziterapija, prižiūrima specialisto, yra efektyvesnè, nes specialistas turi žinių ir įgūdžių pastebèti bei koreguoti pratimus ar laikyseną. Savarankiškai atliekama kineziterapijos procedūra gali būti nesaugi, nes jei asmuo nebus kompetentingas pratimų metu pastebėti klaidų, netaisomos jos gali tapti žalingos. Atliekant kineziterapijos programą savarankiškai, negalima motyvacija ir programos vykdymo kontrolè.

\section{Literatūra}

1. Moshe S, Levin M. Occupational aspects of low back pain. Harefuah 2005;144(7),492-496.

2. Results of the health interview survey of the population of Lithuania. Vilnius: Statistics Lithuania, 2015.

3. Bule M. EUROPREV rekomendacijos: fizinis aktyvumas stiprina sveikatą. Kaunas: Vitae Litera, 2018:23.

4. Shadrina AS, Sharapov SZ, Shashkova TI, Tsepilov YA. Varicose veins of lower extremities: insights from the first large-scale genetic study. PLoS genetics 2019;15(4), e1008110.

https://doi.org/10.1371/journal.pgen.1008110

5. Polinskaja T, Žuravliova T, Žiliukas G, Brasaitė I. Pacientų požiūris ị kojų venų varikozės prevenciją. Visuomenès sveikata, 2015/priedas 1:76-80.

6. Anderson J, Williams AE, Nester C. An explorative qualitative study to determine the footwear needs of workers in standing environments. Journal of Foot And Ankle Research 2017;10(1):41.

https://doi.org/10.1186/s13047-017-0223-4

7. Laird RA, Keating JL,Ussing K, Li P, Kent P. Does movement matter in people with back pain? Investigating 'atypical' lumbopelvic kinematics in people with and without back pain using wireless movement sensors. BMC Musculoskeletal Disorders 2019; 20(1): 28 .

https://doi.org/10.1186/s12891-018-2387-x

8. Purani RS,Vyas NJ, Sheth MS. Prevalence of low back pain in salespersons and its association with ergonomic risk factors in Ahmedabad, Gujarat: a cross-sectional survey. Medical Journal of DPU 2016;9(3):331-335.

https://doi.org/10.4103/0975-2870.182503

9. Dainty RS, Alcorn E, Ferguson CA, Gregory DE. Prevalence of occupation-related pain among baristas and an examination of low back and shoulder demand during the preparation of espresso-based beverages. Ergonomics 2014;57(8):1192-1200. https://doi.org/10.1080/00140139.2014.914582

10. Richards KV, Beales DJ, Smith AJ, O'Sullivan PB, Straker LM. Neck posture clusters and their association with biopsychosocial factors and neck pain in Australian adolescents. Physical Therapy 2016;96(10):1576-1587.

https://doi.org/10.2522/ptj.20150660 
11. Creasy SA, Rogers RJ, Byard TD, Kowalsky RJ, Jakicic JM. Energy expenditure during acute periods of sitting, standing, and walking. Journal of Physical Activity and Health 2016;13(6):573-578.

https://doi.org/10.1123/jpah.2015-0419

12. Ohlendorf D, Erbe C, Nowak J, Hauck I, Hermanns I, Ditchen D, Groneberg DA. Constrained posture in dentistry-a kinematic analysis of dentists. BMC Musculoskeletal disorders 2017;18(1):291. https://doi.org/10.1186/s12891-017-1650-x

13. McRae G, Payne A, Zelt JG, Scribbans TD, Jung ME, Little JP, Gurd BJ. Extremely low volume, whole-body aerobic-resistance training improves aerobic fitness and muscular endurance in females. Applied Physiology, Nutrition and Metabolism 2012; 37(6):1124-1131.

https://doi.org/10.1139/h2012-093

14. Teyhen DS, Childs JD, Dugan JL, Wright AC, Sorge JA, Mello JL, et al. Effect of two different exercise regimens on trunk muscle morphometry and endurance in soldiers in training. Physical Therapy 2013;93(9):1211-1224.

https://doi.org/10.2522/ptj.20120152

15. Simão R, Lemos A, Salles B, Leite T, Oliveira É, Rhea M, Reis VM. The influence of strength, flexibility, and simultaneous training on flexibility and strength gains. The Journal of Strength \& Conditioning Research 2011;25(5):1333-1338. https://doi.org/10.1519/JSC.0b013e3181da85bf

16. Muyor JM, López-Miñarro PA, Casimiro AJ. Effect of stretching program in an industrial workplace on hamstring flexibility and sagittal spinal posture of adult women workers: a randomized controlled trial. Journal of Back and Musculoskeletal Rehabilitation 2012;25(3):161-169.

https://doi.org/10.3233/BMR-2012-0323

17. Lynn SK, Padilla RA,Tsang KK. Differences in static-and dynamic-balance task performance after 4 weeks of intrinsic-footmuscle training: the short-foot exercise versus the towel-curl exercise. Journal of Sport Rehabilitation 2012;21(4):327-333. https://doi.org/10.1123/jsr.21.4.327

\section{CHANGES IN PHYSICAL CHARACTERISTICS AND POSTURE OF BARISTAS USING PHYSIOTHERAPY V. Strukčinskaitė, G. Blauzdžiūnaitė, B. Strukčinskienė, E. Griškonytė, S. Griškonis}

Keywords: physical characteristics, posture, physiotherapy, long-term standing, work environment, barista.
Summary

The article discusses the consequences of long-term standing in baristas ' workplace, and analyzes the influence of physiotherapy on the physical characteristics and posture disordered by baristas' standing work. The aim of the study was to evaluate the effect of physiotherapy on the posture and physical characteristics of baristas. In the study participated baristas, aged 19 to 25 years. There were 16 baristas in the study group and 15 - in the control group (31 in total). There were used the analysis of the scientific literature, and testing. Anthropometric measurements of subjects (height, weight and BMI) were performed. Posture was assessed using the W.W. Hoeger Posture Assessment Scale. Physical characteristics were analyzed using: Ruffier Test (the assessment of aerobic endurance), the assessment of trunk muscles' static endurance according to the McGill methodology, the Spine Mobility Assessment, 90-90 Strait Leg Raise Test, and Y-balance test. The results of the study revealed that $35.5 \%$ of participants before the study did not correspond to excellent posture, $58.1 \%$ - did not meet high aerobic capacity, $41.9 \%$ did not match the abdomen-back and $12.9 \%$ did not meet the norms of static endurance of left-right lateral muscles, and $45.2 \%$ did not meet the PGA norm. Physiotherapy improved all physical characteristics and posture in the study group, but in the control group did not change posture and changed insignificantly their physical characteristics. Analysis of the effectiveness of physiotherapy on study and control groups showed, that physiotherapy performed under the supervision of a professional physiotherapist is more effective, because the specialist has the knowledge and skills to notice and adjust exercises or posture. A self-administered physiotherapy procedure can become unsafe, because the person will not be competent to notice the mistakes being made during the exercise, so these will not be corrected and may become harmful. In addition, when performing a physiotherapy program on your own, motivation cannot be monitored and the implementation of the physiotherapy program cannot be ensured.

Correspondence to: vaiva.struk@gmail.com

Gauta 2020-11-26 